\title{
STRESS SOURCES AND POSSIBILITIES OF DIMINISHING THEM AT ORGANIZATIONAL LEVEL
}

\author{
POPESCU, L. \& POPESCU, V.
}

Abstract: Organizational stress is generated by the events from the organization's life and can have not only positive, incentive effects, but also negative effects as performance abatement, demotivation, resignations, absenteeism etc. In some organizations, managers even want to maintain a certain stress level, considering that this way the employees will be more implied in the development of their activity. Negative consequences appear only when this level exceeds a certain limit.

Stress can appear in any organization, no matter its dimensions, and at the level of European Union, it represent the second big problem of health in work activities.

Therefore, the cognition of the factors that generate and maintain organizational stress is very important, because through their analysis the most effective solutions to reduce this phenomenon can be identified.

Key words: stress, organization, management, motivation, work condition, employee
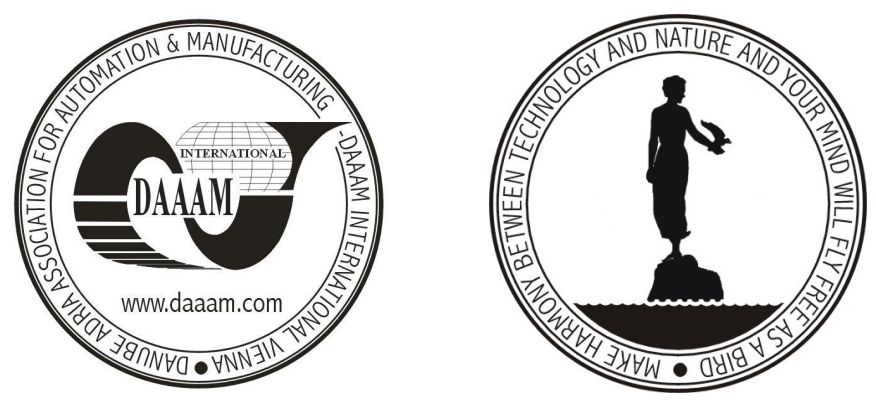

Authors' data: PhD. Popescu, L[uminita]; PhD. Popescu, V[irgil], University of Craiova, Faculty of Economy and Business Administration, Calugareni, nr.1, 220037, Drobeta Turnu Severin, Mehedinti, Romania, flumi@mail.expert.ro, virgil@expert.ro

This Publication has to be referred as: Popescu, L. \& Popescu, V. (2007). Stress Sources and Possibilities of Diminishing them at Organizational Level, Chapter 35 in DAAAM International Scientific Book 2007, B. Katalinic (Ed.), Published by DAAAM International, ISBN 3-901509-60-7, ISSN 1726-9687, Vienna, Austria DOI: 10.2507/daaam.scibook.2007.35 